IRA-International Journal of Management \& Social Sciences

ISSN 2455-2267; Vol.10, Issue 01 (January 2018)

Pg. no. 27-35

Institute of Research Advances

http://research-advances.org/index.php/RAJMSS

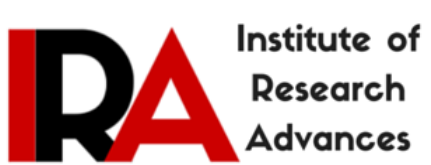

\title{
Influence of Intellectual Capital and Banking Risk through Corporate Perform in the Banking Industry in Indonesia Stock Exchange
}

\author{
Sudirman $^{1}$, Masdar Mas'ud ${ }^{2}$, Lukman Halik $^{3}$, Zainuddin Rahman $^{4}$ \\ Universitas Muslim Indonesia.
}

Type of Review: Peer Reviewed.

DOI: http://dx.doi.org/10.21013/jmss.v10.n1.p3

How to cite this paper:
Sudirman, Mas'ud, M., Halik, L., Rahman, Z. (2018). Influence of Intellectual Capital and Banking Risk
through Corporate Perform in the Banking Industry in Indonesia Stock Exchange.
$\begin{aligned} & \text { IRA-International Journal of Management \& Social Sciences (ISSN 2455-2267), 10(1), 27-35. } \\ & \text { doi:http://dx.doi.org/10.21013/jmss.v10.n1.p3 }\end{aligned}$

(C) Institute of Research Advances.

\section{(c) ) BY-No}

This work is licensed under a Creative Commons Attribution-Non Commercial 4.0 International License subject to proper citation to the publication source of the work.

Disclaimer: The scholarly papers as reviewed and published by the Institute of Research Advances (IRA) are the views and opinions of their respective authors and are not the views or opinions of the IRA. The IRA disclaims of any harm or loss caused due to the published content to any party.

Institute of Research Advances is an institutional publisher member of Publishers Inter Linking Association Inc. (PILA-CrossRef), USA. The institute is an institutional signatory to the Budapest Open Access Initiative, Hungary advocating the open access of scientific and scholarly knowledge. The Institute is a registered content provider under Open Access Initiative Protocol for Metadata Harvesting (OAI-PMH).

The journal is indexed \& included in WorldCat Discovery Service (USA), CrossRef Metadata Search (USA), WorldCat (USA), OCLC (USA), Open J-Gate (India), EZB (Germany) Scilit (Switzerland), Airiti (China), Bielefeld Academic Search Engine (BASE) of Bielefeld University, Germany, PKP Index of Simon Fraser University, Canada. 


\begin{abstract}
This study aims to know and analyze and influence of intellectual capital on corporate performance, analyze the influence of intellectual capital through corporate perform to company value, analyze the influence of intellectual capital to company value, analyze the influence of banking risk through corporate, analyze the influence of banking risk through corporate performance to company value, analyze the influence of banking risk to company value, and analyze the influence of corporate performance value of company. This research is in the form of explanatory research by pooling the data used. This research was conducted on banking sector companies in Indonesia. Observations were made for four consecutive years such us: 2012-2016. Method of analysis of data used models of structural equation modeling (SEM). Result of this study shown: 1) Intellectual capital has a positive and significant effect to corporate performance, 2) Intellectual capital has no significant effect on firm value through corporate performance, 3) Intellectual capital has a positive and significant effect to company value, 4) Banking risk positive and significant impact on corporate performance 5), banking risk has a positive and significant impact on the corporate value through corporate performance, 6). Banking risk has a positive and significant impact on corporate value, 7) Corporate performance has a positive and significant impact on firm value.
\end{abstract}

\title{
Keywords: Intellectual capital, Company Value, Bank Risk, Corporate Perform
}

\section{INTRODUCTION}

Since the 1990s, attention to practice of asset management -intangible (intangible assets) has increased dramatically. One approach used in the assessment and measurement of intangible assets is Intellectual Capital (IC). (Pretty and Guthrie, 2000), (Sullivan, 2000). In accordance with PSAK no.19 seen that the recognition of intangible assets is growing with the recognition of science and being derived from knowledge (computer software, relationships with suppliers / customers, etc.) as elements of intangible assets. In Indonesia, the phenomenon of Intangible Asset has been growing with categorizing knowledge and the things which be derived from knowledge as an element (Ivada, 2004). Intellectual capital is recognized as an intangible asset that is of great value, but until today there have been a lot of companies that have been able to measure, assess and put it on the balance sheet of the company. Still it takes a lot of study and research to measure and quantitatively assess the actual value. (Rahayu, 2006).

Based on Undang-Undang No. 10 Years 1998, the Bank is an entity that collects funds from the public in the form of savings and channels them to the public in the form of loans or other forms in order to improve the living standards of the people. The human factor implied intellectual capital becomes an important element in the banking business. Intellectual capital is part of the intangible asset. But in the conventional system accounting intangible assets not reported in the annual report, so that the annual report may not represent the true value. It is important to do an assessment of the intangible asset so that the annual report be informative, so that the company's value are reported in full by the company whose assets are in the form of intellectual capital.

In general, the business community still has not found the right answer about what the value of the company. This surplus value itself can be derived from a company's ability to produce on customer loyalty to the company. According to Abidin (2000) cite by Sawarjuwono (2003) Intellectual Capital is still not widely known. Besides, these companies have not been paying more attention to human capital, structure capital, and customer capital. All of these are elements of Intellectual capital development of the company. The greatest difficulty in reporting Intellectual Capital and intangible assets is in the assessment. Therefore, the company needs to provide information non-financial related to intellectual capital and intangible assets in order to find a balanced approach in the vote. Improved recognition and utilization of intellectual capital will help the company become more efficient, effective, productive and innovative. In other words, intellectual capital can be improved the performance of the company. (Artinah and Musleh, 2011).

The phenomenon of intellectual capital began in Indonesia, especially after the emergence of PSAK No. 19 about intangible assets. PSAK No. 19 states that intangible assets are non-monetary assets that can be identified and does not have a physical form and held for use in generating or needs product or services, leased to other parties, or for administrative purpose. But in reality, the implementation of intellectual capital in Indonesia is still lacking. It can be seen from the reluctance of companies to pay more attention to the Intellectual capital, in Indonesia tend to use conventional basedin building its business so that the resulting product is still poor technological content. (Kuryanto, et al., 2008). Research on the intellectual capital carried out by some researchers as Firer and Williams (2003), Artinah (2010), Appuhami (2007). Appuhami (2007) found that the relationship of positive and significantly between value added intellectual coefficient (VAIC) with a capital gain on the shares. Bontis, et.al (2000), Guthire.et al (2006) showed a positive relationship between intellectual capital and corporate performance. 
Intellectual capital was first introduced by Jon Kenneth Galbraith in 1969, (Chen et.al, 2011). Intellectual capital is still in the development stage and there is no accepted definition uniformity to identify subcomponents. The intangible assets are generally a corporate intellectual property (such as patents, copyrights and other), goodwill and brand recognition (Chen, et.al, 2011). Marr and schiuma (2001) defines intellectual capital cited by Starovic, et.al (2003) explains that intellectual capital is the knowledge that a group of assets and organizational attributes exhibited significantly contribute to improve the competitive position by adding value to the stakeholder. Smedlund and Poyhonen (2005) in Rupidara (2005) describe the intellectual capital as the capability of the organization to create, make transfers, and implementing knowledge. Williams (2001) defines intellectual capital as the information from the knowledge that is applied in the work to create value. Son (2014) describes the intellectual capital is a device that is needed to find opportunities and manage threats in the life of

Organization for Economic Co-operation and Development (OECD, 1999) described the intellectual capital as the economic value of two categories of intangible assets: 1) organizational structure capital and 2), human capital. More precisely structure organizational capital refers to things such as system software, network distribution and supply chain. Structural capital is the ability of the organization or company to meet the routine processes of companies and the structure that supports employee efforts to produce optimal intellectual performance as well as overall business performance. Human capital includes human resources within the organization and external resources associated with organizations such as consumers and suppliers. Bontis (2004) states that human capital is a combination of knowledge, skill, ability to innovate and the ability to complete the task. Human capital realized the creation of sources of innovation and progress of a company. Customer capital is the intellectual capital components which provide real value. Relational capital is a harmonious relationship which is owned by the company with the stakeholders (Sawarjuwono and Kadir, 2003)

One of the methods used to measure intellectual capital is a method VAIC (Value added intellectual capital) developed by Pulic (1998), designed to present the information about value creation efficiency of intangible assets (tangible assets) of intangible assets (intangible assets) owned by the companies. Value added is calculated as the difference between output and input (Pulic, 1998). Value added intellectual coefficient (VAIC) is the measurement indirect method to measure how and as the efficiency of intellectual capital and capital employees create value based on the relationship the main components, namely capital employee, human capital and structural capital (Pulic, 1998). Intellectual Capital is a resource owned by the company in the form of expertise, knowledge and skills of employees of the company. Intellectual capital is also in the form of system information, patents, policies, processes and systems developed by the company from time-to-time. In addition to these two, intellectual capital is also the form of the company's ability to manage the funds owned.

This research is expected to provide benefits for the company to give more attention in the form of a balanced development and utilization and maximum on intellectual capital to improve the company's performance and be able to attract many investors. In addition, as consideration investors to determine investment decisions at the right company in order to obtain return stocks the form the huge of gain capital to the future. A company's performance is the level of achievement in order to achieve company goals (Simanjuntak, 2005). A company's performance is the result of management decisions to achieve a certain goal effectively and efficiently (Mulyadi, 2007). According to the Indonesian Financial Accounting Standards (PSAK) performance of the company can be measure by analyzing and evaluating financial statements.

Based on the description of the background in the study of intellectual influence on capital gains through corporate perform principal problem can be stated as follows: 1). Whether intellectual capital consisting of capital value added employee, value added human capital and structural capital value added influence on corporate perform,2). Whether intellectual capital consisting of capital value added employee, value added human capital and structural capital value added through performing corporate influence on the value of the company. 3). Whether intellectual capital consisting of capital value added employee, value added human capital and structural capital value added effect on the value of the company. 4) Is the effect on banking risks corporate performing 5) Is the risk of banking through performing corporate influence on the value of the company, 6). Is banking risks affects the value of the company 7). Is performing corporate influence on the value of the company.

\section{METHODOLOGY}

This research is a survey research in the form of explanatory (explanatory research) this research using polling data, namely the merger between the data time series and cross section to get the value of influence intellectual capital on the financial performance. The data used in this research is secondary data derived from the annual report period December 2013 - December 2016. The financial statements have been obtained through the official website of Bank Indonesia (www.bi.go.id) and the official website of each bank on the Stock 
Exchange (www.jsx.co.id). The population of this study are all banking companies (banks) operating in Indonesia in 2013 to 2016 and regularly (quarterly) reports its financial position to Bank Indonesia comprising the total sample is composed of 130 Bank Owned Banks as many as five (5), national private commercial bank (BUSN) exchange a total of 35 (thirty five), BUSN Non exchange a total of 36 (thirty six), Bank of regional development (BPD) by 26 (twenty-six), Bank mixtures as many as 17 (seventeen) and foreign banks 11 (eleven). The sampling technique used in this research is purposive sampling method of data analysis using Structural Equation Model (SEM). The conceptual framework of this study such us :

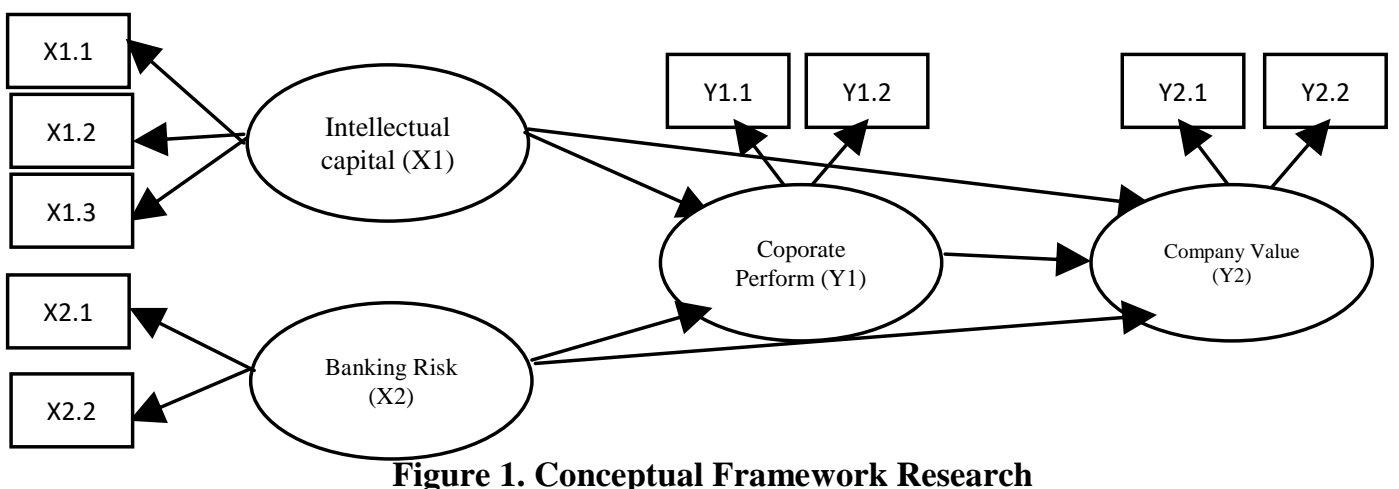

\subsection{Operational definitions of variables are as follows:}

1. Intellectual Capital (X1) with the measurement dimensions: (X1.1) Value added capital employee (Vace), (X1.2) Value Human capital added (VAHC), (X1.3) value added structural capital (VASC).

2. Banking risks (X2) with dimensions of measurement consisting of: (X2.1) Net Interest Margin (NIM), and (X2.2) Loan to Deposit Ratio (LDR)

3. Corporate Perform (Y1) consists of dimensional measurement: (Y1.1) Return on investment (ROA), (Y1.2) Return on equity (ROE)

4. Enterprise value (Y2) with dimensions of measurement: (Y2.1) Price Earn Ratio (PER) and (Y2.2) Earning per share (EPS).

\subsection{The hypothesis in this study is:}

1. Intellectual capital consisting of value added capital employee, value added human capital and structural capital value added effect on corporate perform,

2. Intellectual capital consisting of value added capital employee, value added human capital and structural capital value added through performing corporate influence on the value of the company.

3. Intellectual capital consisting of capital value added employee, value added human capital and structural capital value added effect on the value of the company.

4. banking risks affect the Corporate performing

5. banking risk through Performing corporate an effect on the value of the company,

6. banking risks affect the value of the company

7. Corporate perform affect the value of the company.

\section{RESULT}

\subsection{Intellectual Capital (X1)}

Table. 1 Development of Value Added Capital Employed (Vace) 2013-2016

\begin{tabular}{|c|c|c|}
\hline Year & Average (\%) & Progress (\%) \\
\hline 2013 & 58.402 & - \\
\hline 2014 & 54.380 & -6.89 \\
\hline 2015 & 53.796 & -1.07 \\
\hline 2016 & 60.067 & 11.66 \\
\hline Average & $\mathbf{5 6 . 6 6 1}$ & $\mathbf{1 . 2 3}$ \\
\hline
\end{tabular}

Table. 2 Development of Human Capital Value Added (VAHC) 2013-2016

\begin{tabular}{|c|c|c|}
\hline Year & Average (\%) & Progress (\%) \\
\hline 2013 & 53.121 & - \\
\hline 2014 & 50.936 & -4.06 \\
\hline 2015 & 48.793 & -4.26 \\
\hline 2016 & 55.000 & 12.72 \\
\hline Average & $\mathbf{5 1 . 9 6 9}$ & $\mathbf{1 . 4 7}$ \\
\hline
\end{tabular}


Table 3 Development of Value Added Structural Capital (VASC) 2013-2016

\begin{tabular}{|c|c|c|}
\hline Year & Average (\%) & Progress (\%) \\
\hline 2013 & 0.976 & - \\
\hline 2014 & 0.974 & -0.27 \\
\hline 2015 & 0.974 & -0.02 \\
\hline 2016 & 1.088 & 11.70 \\
\hline Average & $\mathbf{1 . 0 0 3}$ & $\mathbf{3 . 8 1}$ \\
\hline
\end{tabular}

3.2 Banking risks (X2)

Table. 4 Development of Net Interest Margin (NIM) 2013-2016

\begin{tabular}{|c|c|c|}
\hline Year & Average (\%) & Progress (\%) \\
\hline 2013 & 5.786 & - \\
\hline 2014 & 5.298 & -8.43 \\
\hline 2015 & 5.064 & -4.43 \\
\hline 2016 & 5.018 & -0.90 \\
\hline Average & $\mathbf{5 . 2 9 1}$ & $\mathbf{- 4 . 5 9}$ \\
\hline
\end{tabular}

Table. 5 Development Loan to Deposit Ratio (LDR) 2013-2016

\begin{tabular}{|c|c|c|}
\hline Year & Average (\%) & Progress (\%) \\
\hline 2013 & 86.512 & - \\
\hline 2014 & 83.658 & -2.30 \\
\hline 2015 & 85.442 & 2.13 \\
\hline 2016 & 84.176 & -1.48 \\
\hline Average & $\mathbf{8 4 . 9 4 7}$ & $\mathbf{- 0 . 8 8}$ \\
\hline
\end{tabular}

3.3 Corporate Performance (Y1)

Table. 6 Forms Return On Asset (ROA) 2013-2016

\begin{tabular}{|c|c|c|}
\hline Year & Average (\%) & Progress (\%) \\
\hline 2013 & 1.68 & - \\
\hline 2014 & 1.42 & -15.58 \\
\hline 2015 & 1.00 & -29.77 \\
\hline 2016 & 1.05 & 4.95 \\
\hline Average & $\mathbf{1 . 2 8 8}$ & $\mathbf{- 1 3 . 4 7}$ \\
\hline
\end{tabular}

Table. 7 Development of Return On Equity (ROE) 2013-2016

\begin{tabular}{|c|c|c|}
\hline Year & Average (\%) & Progress (\%) \\
\hline 2013 & 7.877 & - \\
\hline 2014 & 8.224 & 4.40 \\
\hline 2015 & 5.824 & -29.18 \\
\hline 2016 & 3.797 & -34.79 \\
\hline Average & $\mathbf{6 . 4 3 1}$ & $\mathbf{- 1 9 . 8 6}$ \\
\hline
\end{tabular}

3.4 Corporate value (Y2)

Table. 8 Developments Price Earning Ration (PER) 2013-2016

\begin{tabular}{|c|c|c|}
\hline Year & Average (\%) & Progress (\%) \\
\hline 2013 & 13.358 & - \\
\hline 2014 & 17.650 & 32.15 \\
\hline 2015 & 21.589 & 22.31 \\
\hline 2016 & 23.548 & 9.07 \\
\hline Average & $\mathbf{1 9 . 0 3 6}$ & $\mathbf{2 1 . 1 8}$ \\
\hline
\end{tabular}


Table. 9 Developments Earning Per Share (EPS) 2013-2016

\begin{tabular}{|c|c|c|}
\hline Year & Average (\%) & Progress (\%) \\
\hline 2013 & 132.576 & - \\
\hline 2014 & 129.712 & -2.16 \\
\hline 2015 & 124.233 & -4.22 \\
\hline 2016 & 126.634 & 1.93 \\
\hline Average & $\mathbf{1 2 8 . 2 8 8}$ & $\mathbf{- 1 . 4 8}$ \\
\hline
\end{tabular}

\subsection{Test of Normality Data}

Table. 10 Assessment of normality

\begin{tabular}{|c|r|r|r|r|r|r|}
\hline Variable & \multicolumn{1}{c|}{ Min } & \multicolumn{1}{c|}{ Max } & \multicolumn{1}{c|}{ Skew } & \multicolumn{1}{c|}{ cr } & \multicolumn{1}{c|}{ Kurtosis } & \multicolumn{1}{c|}{ cr } \\
\hline X11 & 1,013 & 5,063 & -.246 & -1272 & -.591 & -1527 \\
\hline Y22 & .494 & .099 & -.186 & -.962 & -.622 & -1607 \\
\hline Y21 & 1,013 & 5,063 & -.074 & -.384 & -.680 & -1755 \\
\hline Y12 & .180 & .480 & -.438 & -2263 & .679 & 1,753 \\
\hline Y11 & 2,329 & 4,556 & -.357 & -1842 & .098 & .254 \\
\hline X22 & 1013 & 5063 & -.527 & -2720 & -.221 & -.570 \\
\hline X21 & .495 & .099 & -.687 & -3546 & .102 & .262 \\
\hline X13 & 1,053 & 5,263 & -.671 & -3463 & -.358 & -.925 \\
\hline X12 & 1213 & 6063 & -.207 & -1071 & -.341 & -.881 \\
\hline Multivariate & & & & & -1736 & -.780 \\
\hline
\end{tabular}

Results of normality data test presented show that in univariate from 9 dimensions measuring only 7 normally distributed while the rest were not normally distributed, namely X21 and X13.

\subsection{Functional Relationships Between Variables}

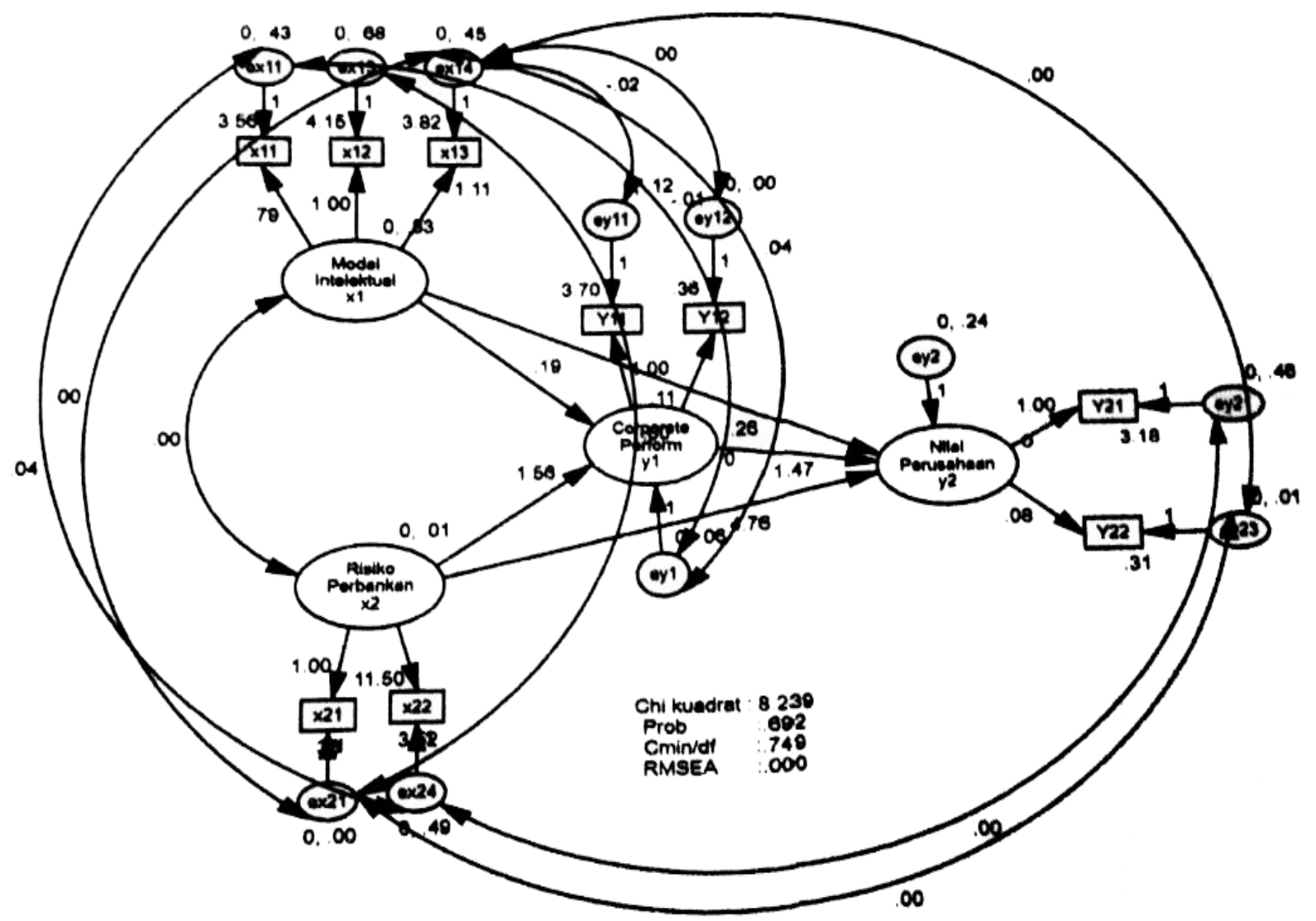

Figure 2. Structural Equation Model (SEM) 


\begin{tabular}{|c|c|c|c|c|c|c|}
\hline Independent Variable & $\begin{array}{c}\text { Direction } \\
\mathrm{s} \\
\end{array}$ & Estimate & SE & TValue & Prob & Result \\
\hline Intellectual Capital (X1) & $\begin{array}{l}\mathrm{X} 1 \rightarrow \mathrm{Y} 1 \\
\mathrm{X} 1 \rightarrow \mathrm{Y} 2\end{array}$ & $\begin{array}{l}0.189 \\
0.256\end{array}$ & $\begin{array}{l}0.049 \\
0.137\end{array}$ & $\begin{array}{l}3.846 \\
1.872\end{array}$ & $\begin{array}{l}0.000 \\
0.061\end{array}$ & $\begin{array}{c}\text { Sig } \\
\text { No Sig }\end{array}$ \\
\hline Banking Risk (X2) & $\begin{array}{l}\mathrm{X} 2 \rightarrow \mathrm{Y} 1 \\
\mathrm{X} 2 \rightarrow \mathrm{Y} 2\end{array}$ & $\begin{array}{l}1.555 \\
4.757\end{array}$ & $\begin{array}{l}0.471 \\
1.516\end{array}$ & $\begin{array}{l}3.306 \\
3.139\end{array}$ & $\begin{array}{l}0.000 \\
0.002\end{array}$ & $\begin{array}{l}\text { Sig } \\
\text { Sig }\end{array}$ \\
\hline Corporate Perform (Y1) & $\mathrm{Y} 1 \rightarrow \mathrm{Y} 2$ & 1.466 & 0.453 & 3.239 & 0.001 & Sig \\
\hline
\end{tabular}

Effect of variable intellectual capital (X1) on corporate performed (Y1) of 0189 with a t value of 3,846 with a standard error (SE) worth of 0.049 is at a significance level of 0.000 . The coefficient indicates that the intellectual capital variable (X1) positive effect on corporate performed (Y1). This means that increasing the intellectual capital (X1) will be followed by an increase in corporate performed (Y1) assuming other factors that affect the size of corporate perform (Y1) is considered constant. Rated statistical t-test the effect of intellectual capital (X1) to perform corporate (Y1) of 3846 to 0000 or the significance of $<0.05$. This means the intellectual capital (X1) positive and significant impact on corporate performed (Y1).

The effect of intellectual capital variable coefficient (X1) to the enterprise value (Y2) amounted to 0.256 with a $t$ value of 1.872 with a standard error (SE) worth 0.137 at significance level of 0061 . The coefficient indicates that the intellectual capital variable (X1) does not significantly affect the company's value (Y2).

Variable banking risks (X2) to perform corporate (Y1) of 0.155 with a t value of 3,306 with a standard error niali 0471 valued at 0.000 significance level suggesting that banking risks (X2) have positive influence on corporate performed (Y1).

Variable banking risks (X2) to firm value (Y2) of 4757 with niali of 3,139 t valued at 1.516 with a standard error that otherwise variable banking risks (X2) has a positive effect on firm value (Y2).

Corporate perform (Y1) to firm value (Y2) amounted to 1,466 with t value of 3,239 with a standard error amounting to 0453 at a significance level of 0.001 so stated that corporate performed (Y1) positive and significant effect on firm value (Y2)

The indirect effect of intellectual capital and banking risks to corporate value through corporate performed as described in the table below:

Table. 11 Indirect Effect

\begin{tabular}{|l|c|}
\hline \multicolumn{1}{|c|}{ Description } & Value \\
\hline $\begin{array}{l}\text { indirect effect of intellectual capital on corporate value through } \\
\text { corporate performed }\end{array}$ & 0277 \\
\hline $\begin{array}{l}\text { indirect effect of bank risk on the value of the company through } \\
\text { corporate performed }\end{array}$ & 2,280 \\
\hline
\end{tabular}

Based on the table above can be interpreted as follows:

1. The effect of indirect intellectual capital (X1) to firm value (Y2) through corporate performed (Y1) is equal to 0277 . This indicates that the current intellectual capital increase will improve corporate performed so that it will raise the value of the company for 0277

2. Effect of indirect banking risks (X2) to firm value (Y2) through corporate performed (Y1) is equal to 2,280. This indicates that the current banking risk increases will improve corporate performed so that it will raise the value of the company amounted to 2,280

Table. 11 Total Effect

\begin{tabular}{|l|c|}
\hline \multicolumn{1}{|c|}{ Description } & Value \\
\hline The effect of intellectual capital on company value & 0.533 \\
\hline Effect of total banking risk to value of the company & 7037 \\
\hline
\end{tabular}

Based on the table above can be interpreted as follows:

1. The net effect of intellectual capital (X1) to niali companies (Y2) is equal to 0.533. This indicates that the effect of intellectual capital can increase the value of the company through the merger of direct and indirect influences of 0.533 
2. Effect of total banking risks (X2) to firm value (Y3) is equal to 7.0387. This indicates that the total effect of bank risk will decrease the value of the company through the merger of direct or indirect effect by 7037 .

\section{DISCUSSION}

The influence of the corporate intellectual capital variables are positive and significant perform. These results give an interpretation that intellectual capital increase will be followed by an increase in corporate performed assuming other factors that affect the size of the intellectual capital is considered constant. Disclosure of information will give a positive signal and a negative for the market reaction (eg, changes in stock prices). It is said to give a positive signal if there is a stock price increase will affect the amount of return so that an impact also on the capital gain obtained invest. But otherwise the disclosure is said to be a negative impact if it gives a negative signal. In this case the disclosure intellectual capital is necessary for investors in consideration of investment decision.

Intellectual capital variable effect on firm value is not significant. These results give an interpretation that increasing the intellectual capital will not be followed by an increase in the value of the company, assuming other factors that affect the size of the intellectual capital is considered constant. This means that the intellectual capital consisting of capital value added employee (VACE), value added human capital (VAHC), value added structural capital (VASC) which produce components of the calculation of output and input. Output consists total number of loans and other income.

Influence of the corporate banking risk variables are positive and significant perform. The results give an interpretation that the increase in bank risk will be followed by an increase in corporate performed assuming other factors that affect the size of the banking risk is considered constant. Banking risk variables influence on corporate value is positive and significant. These results give an interpretation that the increase in bank risk will be followed by an increase in the value of the company, assuming other factors that affect the size of bank risk held constant

Variable corporate perform Influence perform on corporate value is positive and significant. These results provide interpretation of that increase will be followed by a corporate perform growth enterprise value, assuming other factors that affect the size of corporate perform held constant.

\section{FINDINGS}

Implications of the theory can be put forward in this study is that the value of the company was affected by intellectual capital, banking risk and corporate performed, either directly or indirectly, while the implications of the findings empirically in this research is the obtainment of a formulation of the increase in the value of the company, namely through increasing the intellectual capital, risk corporate banking and perform.

\section{LIMITATION}

There are many variables that have not been accommodated in this model, such as firm size, leverage, profitability, corporate governance and ownership structure that is also a contributing factor in the increased value of the company and these variables can be added so that more enriched the research becomes.

\section{REFERENCES}

[1] Abidin, Sawarjuwono and Kadir, 2003, the "Intellectual Capital Disclosure Commitment: Myth or Reality?", Journal of Intellectual Capital, Vol.13, No. 1, pp. 39-56

[2] Appuhami, Ranjith, 2007. "The Impact of Intellectual Capital on Investor's Capital Gains on Shares: an Empirical Investigation In Thai Banking, Finance and Insurance Sector". Journal of Internet Banking and Commerce, Vol. 3, No. 2, pp. 14-25

[3] Artinah, Budi, Ahmad Musleh. 2011. Effect of Intellectual Capital Against Capital Gains (Empirical Study Of Banking Companies Listed in Indonesia Stock Exchange). Spread Journal. Volume 1. No. 1. April 2011.

[4] Bontis, N., Keow, WCC, Richardson, S. 2000. "Intellectual capital and business performance in Malaysian Industries.

[5] Chen et al. An empirical investigation of the relationship between intellectual capital and firms' market value and financial performance. Journal of Intellectual Capital Vol. 6 No. 2, 2008

[6] Firer, s. and Williams, SM 2003, "Intellectual capital and traditional measures of corporate performance", Journal of Intellectual Capital, Vol. 4 3, p. 348.

[7] Ivada, Elvia, 2004. "The perception on Recognition Accounting \& Reporting Intellectual Capital". Journal of Accounting 
[8] Kuryanto, B. 2008. "The Effect of Intellectual Capital on Firm Performance". Accounting National Symposium XI. Pontianak.

[9] Marr, B. and G. schiuma. 2001. Measuring and Managing Intellectual Capital and Knowledge Assets in New Organization. Handbook of Performance Measurement, M. Bourne (ed). London: Gee.

[10] Petty, P. and J. Guthrie, 2000. "Intellectual capital literature review: measurement, reporting and management". Journal of Intellectual Capital. Vol. 1 No. 2. Pp. 155-75

[11] Pulic, A, 1998. "Measuring the performance of intellectual potential in the knowledge economy". Paper presented at McMaster 2nd Word Congress on Measuring and Managing Intellectual Capital by the Austrian Team for Intellectual Potential.

[12] RahayuKurnia, et al, 2006, "KonsepPerpajakan, TeoridanMasalah" (Taxation Concepts, theories, and issues), PT. Kencana, Jakarta

[13] Rupidara, Neil, S.2008. "Modal Intelektul, StrategiPengembanganOrganisasidanSumberDayaManusia (Intellectual Capital and Organizational Development Strategy and Human Resources). Christian University Satya Wecana

[14] Sullivan Jr., PH and PH Sullivan Sr, 2000. "Valuing intangible companies, an intellectual capital approach". Journal of Intellectual Capital. Vol 1 No. 4. pp. 328-340.

[15] William. (2001), "PengantarEkonomiMikro(Introduction of Microeconomics). Jakarta PT.Salemba Four 